\title{
SELF-EFFICACY AND RESILIENCE STATUS AMONG FAMILY CAREGIVERS OF CANCER PATIENTS IN TURKEY
}

BASKENT UNIVERSITY 2
A. Karaaslan Eser ${ }^{1}$, S. Kav ${ }^{1}$, Z. Uğurlu' ${ }^{1}$, B. Cevik ${ }^{1}$, Ö. Alparslan Atar ${ }^{2}$, H. Ozencakir ${ }^{3}$, A. Karabulut ${ }^{3}$, E. Citak ${ }^{1}$ ${ }^{1}$ Baskent University Faculty of Health Sciences, Nursing, Ankara, Turkey; ${ }^{2}$ Baskent University Adana Hospital, Nursing Directorate, Adana, Turkey. ${ }^{3}$ Baskent University Ankara Hospital, Nursing Directorate, Ankara, Turkey

\section{ABSTRACT}

Introduction: In diseases requiring long-term care such as cancer, the patients' problems affect both patients and family caregivers. Selfefficacy and psychological resilience can influence family members to cope with the problems they experience during the caregiving process. Objectives: The aim of this study was to determine the status of psychological resilience and self-efficacy among family caregivers of cancer patients.

Methods:The study has been conducted at two ambulatory treatment centers of medical oncology department affiliated with a university hospital. Sample was included the 157 family caregivers of patients with cancer over 18 years and volunteer to participate. In data collection, socio-demographic data form, Turkish version of the Connor-Davidson Resilience Scale (CD-RISC) and Self-efficacy scale were used.

Results:The mean age of the participants were $46.32 \pm 14.8$ (range: 19 73 years). Half of them were male $(51.8 \%)$, and university graduates (56.4\%). Mean duration of the caregiving was $26.42 \pm 26.32$ (range 2180) months and $52.3 \%$ of them were spouse. One in third of the patients $(38.7 \%)$ diagnosed with gynecologic cancers and $27.4 \%$ of them were described as dependent to the caregivers. Self-efficacy scale mean was $87.81+13.43$ (range: $35-111$ ) and $69.34 \pm 16.75$ (range: $24-100$ ) for CD-RISC. Male caregivers had higher self-efficacy scale scores and positive acceptance of change $(p<0.05)$. A positive significant correlations were found between self-efficacy scale and CD-RISC scores $(r: 0.26 ; p<0.004)$

Conclusions: Our results showed that caregivers reported moderate level of resilience and self-efficacy.

\section{METHODS}

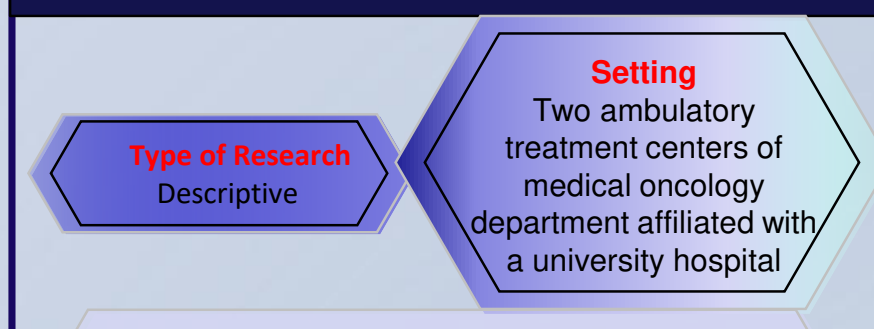

Sample

157 family caregivers of patients with cancer over 18 years, and volunteer to participate were included

\section{DATA COLLECTION}

Demographic Form 20 item questionnaire including caregiving characteristics.

Self-efficacy scale (Sherer et al, 1982) It's a 23 item, 5 Likert-type self-evaluation scale with four dimensions. Translated into Turkish by Gozum and Aksayan (1999). Cronbach's Alpha value in this study 0.84 .

Connor-Davidson Resilience Scale (Connor \& Davidson, 2003) 25-item self-report scale, rated on a 5 -point scale (0-4), consist of 3 dimensions; validated into Turkish by Karaırmak (2010). Higher scores reflecting greater resilience. Cronbach's Alpha value in this study 0.78 .

\section{RESULTS}

Sample Characteristics

The mean age was $46.32 \pm 14.8$ (range: 19 and 73 years). Half of them were male $(51.8 \%)$, married $(71.4 \%)$, had children $(64.2 \%)$ and university graduates $(56.4 \%)$

Diagnosis of the patients were gynecologic $(44.6 \%)$, GI $(28.2 \%)$ and breast cancer (17.4\%); $45.2 \%$ had comorbid diseases and $27.4 \%$ of them were described as dependent to the caregivers.

The mean duration of caregiving was $26.42 \pm 26.32$ (min:2max: 180 months), $52.3 \%$ of them were spouse and one in third of the caregivers (32.1\%) were actively working.

Caregivers supported their patients' to meet physical needs $(44 \%)$, housekeeping $(78 \%)$, shopping $(94 \%)$ and transportations $(83 \%)$.

Mean Scores From SES and CD-RISC dimensions

\begin{tabular}{|c|c|c|}
\hline SCALES & Mean \pm SD & $\begin{array}{l}\text { Scale score } \\
\text { range }\end{array}$ \\
\hline $\begin{array}{l}\text { Total } \\
\text { Self-Efficacy Scale }\end{array}$ & $87.81 \pm 13.4$ & $35-111$ \\
\hline Starting Behavior & $31.58 \pm 6.60$ & $8-40$ \\
\hline Continuing Behavior & $26.74 \pm 5.82$ & $7-35$ \\
\hline Behavior completion & $19.39 \pm 3.82$ & $5-25$ \\
\hline Fight with obstacles & $9.52 \pm 2.79$ & $3-15$ \\
\hline $\begin{array}{l}\text { Total } \\
\text { Connor-Davidson } \\
\text { Resilience Scale }\end{array}$ & $69.34 \pm 16.75$ & 24-100 \\
\hline Tenacity & $44.34 \pm 10.89$ & $12-60$ \\
\hline Strength & $14.64 \pm 5.36$ & $1-24$ \\
\hline Optimism & $10.35 \pm 2.99$ & $3-16$ \\
\hline \multicolumn{3}{|c|}{$\begin{array}{l}\text { Male caregivers had higher self-efficacy scale scores and } \\
\text { positive acceptance of change }(p<0.05) \text {. }\end{array}$} \\
\hline \multicolumn{3}{|c|}{$\begin{array}{l}\text { A positive significant correlations were found between } \\
\text { self-efficacy scale and CD-RISC scores }(r: 0.26 ; p<0.004) \text {. }\end{array}$} \\
\hline
\end{tabular}

\section{CONCLUSIONS}

The results of this study indicate that caregivers of patients with cancer have moderate levels of resilience and self-efficacy. In addition, a significant, positive relationship is determined between self-efficacy and resilience.

Education programs might be effective for improving caregivers' resilience and self-efficacy. Further research with supportive interventions is needed.

\section{REFERENCES}

1. Hwang IC, Kim YS, Lee YJ, Choie YS, Hwang SW, Kim HM, Koh SJ.( 2018). Factors Associated With Caregivers' Resilience in a Terminal Cancer Care Setting. Am J Hosp Palliat Care, 35(4):677-683.

Yıldız E, Karakaş SA, Güngörmüş Z, Cengiz M. (2017). Levels of Care Burden and Self-Efficacy for Informal Caregiver of Patients with Cancer. Holist Nurs Pract, 31(1):7-15

Karaırmak Ö (2010). Establishing the psychometric qualities of the Connor-Davidson Resilience Scale (CD-RISC) using exploratory and confirmatory factor analysis in a trauma survivor sample. Psychiatry Research, 179 (3): 350-356

4. Gözüm S \& Aksayan S (1999). Öz-yeterlik ölçeginin Türkçe formunun güvenirlik ve geçerligi (Reliability and validity of Turkish version of self-efficacy scale). Atatürk Üniversitesi HYO Dergisi, 2 (1): 21-34. 